\title{
Egyptian and Middle Eastern mummies in public museums outside Egypt
}

\author{
Charbel El-Bcheraoui, Oliver Dutour, Gilles Boëtsch
}

UMR 6578 - Université de la Méditerranée, Faculté de Médecine 27 Bd Jean Moulin I 3385 Marseille Cédex 05

KEY WORDS: mummies, middle east, Egypt, museums, studies.

\section{ABSTRACT}

The issue of this work is to locate the collections of Egyptian and Middle Eastern mummies around the world. To do so, we have taken contact with several museums around the world (we can mention the British Museum, the Louvre, the Smithsonian Institution, the museum of Torino...), consulted many publications concerning these mummies in addition to visiting lots of net sites build about this subject.

In result, we have approximatively succeeded to get the number of these mummies, their taphonomy - trying to show the degree of concern between the museums and the methods of their conservation - and the documentations made about them. This work puts the light mostly on mummies not really known worldwide.

\section{Introduction}

Nothing before has ever captured the attention of humans like Egyptian mummies.

A visit to any museum or historical site in Egypt would reveal a huge number of mummies representing the people that long time ago settled down on this land.

These mummies are no more the unique mummies on earth like we always thought till the 20th century. Many other people have also believed in the human body preservation so they can give their dead the chance of a later life like ancient Palmyrians, Inca and Chinese. If the mummies of the Louver or the British Museum are the most famous, other museums in the world also contain mummies as important as the last ones either they were originated from Egypt or other Middle Eastern countries. The aim of this abstract is to locate these mummies and put them into an inventory. Where are these mummies, how old are they, the state of their preservation, the studies and the publications concerning them are the question that we asked ourselves. To answer that question we consulted many Internet sites, publications and sent letters to certain museums to ask information about their collections.

\section{Method}

Surfing the net made our job easier in many ways because most of the world's museums have official sites. This is how we were able to know which museums have at least Egyptian collections or cite implicitly the possession of mummies included in their collections. Letters have been sent to these museums to ask about their collections.

Many Internet sites, like the one of Mr. James DEEM or the Egyptology site if the United Kingdom, are made by researchers concerned by mummies.

Different publications served us as data bases for certain mummies, especially the Palmyrian mummies, the Lebanese mummies and the Egyptian mummies conserved in different countries like Italy, Uruguay and Denmark.

\section{Results}

At the end, we were able to list $35 \mathrm{I}$ human complete mummies.

The results of our inquiry are listed, in a table (Tab. I), in the alphabetical order of the countries where the museums are situated.

The census of the Egyptian mummies' collections in Italy has been accomplished by Ezio FULCHERI, Partrizia BARACCHINI,Tiziana DORO GARETTO,Annamaria PASTORINO and Emma RABINO MASSA in 1994 under the next title: «Le Mummie Dell'Antico Egitto Custodit Nei Musei Italiani»s. Table 2 is taken out of this publication. France and the United Kingdom's museums are represented respectively in table 3 and 4 .

\section{Discussion}

The census of Egyptian and Middle Eastern mummies is a prior and essential inventory for every researcher in the 
Egyptian and Middle Eastern mummies in public museums outside Egypt

\begin{tabular}{|c|c|c|c|}
\hline Country & Museum & Complete & Incomplete \\
\hline \multirow[t]{2}{*}{ Germany } & Roemer and Pelizaeus Museum & $2 E^{*}$ & \\
\hline & Landesmuseum in Oldenburg & & IE \\
\hline Austria & Kunsthistorisches Museum & $24 \mathrm{E}$ & \\
\hline \multirow[t]{2}{*}{ Croatia } & Archaeological Museum in Zagreb & $4 \mathrm{E}$ & \\
\hline & Dubrovnik Archaeological Museum & & $3 \mathrm{E}$ \\
\hline Denmark & Ny Carlsberg Museum & $4 \mathrm{E}, \mathrm{I}$ P* & \\
\hline Spain & Egyptian Museum Of Barcelona & $2 \mathrm{E}$ & \\
\hline \multirow[t]{6}{*}{ United States } & Amiston Museum & IE & \\
\hline & Art Institute of Chicago & IE & \\
\hline & Michael C. Carlos Museum & $2 \mathrm{E}$ & \\
\hline & Oriental Institute Museum & $3 \mathrm{E}$ & \\
\hline & Rosicrucian Museum & $8 \mathrm{E}$ & \\
\hline & $\begin{array}{l}\text { University of Memphis Institute of Egyptian } \\
\text { Art and Archaeology }\end{array}$ & IE & \\
\hline France & & $47 \mathrm{E}$ & $8 \mathrm{E}$ \\
\hline Greece & National Archaeological Museum in Athens & $10 \mathrm{E}$ & \\
\hline \multirow[t]{2}{*}{ Holland } & Allard Pierson Museum & IE & \\
\hline & Rijksmuseum Van Oudheden & $31 \mathrm{E}$ & $28 \mathrm{E}$ \\
\hline |taly & & $|4| \mathrm{E}$ & $214 \mathrm{E}$ \\
\hline Lebanon & National Museum Of Beyrouth & $8 L^{*}$ & \\
\hline $\begin{array}{l}\text { United } \\
\text { Kingdom }\end{array}$ & & $55 \mathrm{E}$ & $2 \mathrm{E}$ \\
\hline Syria & Palmyra Museum & $4 P$ & IP \\
\hline Uruguay & Egyptian Museum in Montevideo & IE & \\
\hline TOTAL & & 338 E, 5 P, 8 L & $256 \mathrm{E}, \mathrm{I} P$ \\
\hline
\end{tabular}

Table 1 - Collections of mummies found in public museums. * $E=$ Egyptians; $P=$ Palmyrians; $L=$ Lebanese.

Egyptology, archaeology, ethnology and medicine field desiring to find a mummy from these two origins with certain criteria like nature, age, sex, pathology, etc...

Our results come from valid and accessible sources.

We were able, through this work, to locate 64 collections of mummies in 14 countries. I of them was Lebanese, 2 were Palmyrians and $6 \mathrm{I}$ were Egyptians. These collections are made of 338 complete Egyptian mummies, 256 incomplete, 5 Palmyrian complete mummies, I incomplete and 8 complete Lebanese mummies. These numbers do not take animal mummies into consideration.

\section{State of preservation}

Concerning the state of preservation of the mummies we've found, it could variate between «very good» and «bad». The concern towards these mummies is also very varied.

\begin{tabular}{|c|c|c|c|}
\hline City & Museum & Complete & Incomplete \\
\hline Pisa & Ist. Anatomia Patologica & 2 & \\
\hline Napoli & Museo di Antropologia & & 6 \\
\hline Roma & Ist. Di Antropologia & I & \\
\hline Padova & Ist. Di Antropologia & 1 & \\
\hline Torino & Ist. Di Antropologia & 7 & 165 \\
\hline Torino & Museo Egizio & 71 & 5 \\
\hline Susa & Museo Civico & & 6 \\
\hline Asti & Museo Civico & 2 & \\
\hline Alba & Museo Civico & & I \\
\hline Vercelli & Museo Leone & & I \\
\hline Biella & Museo Civico & I & \\
\hline Novara & Museo Civico & & 4 \\
\hline Milano & $\begin{array}{l}\text { Museo Castello } \\
\text { Sforzesco }\end{array}$ & I & \\
\hline Bergamo & Museo Archeologico & I & \\
\hline Como & Museo Civico & I & \\
\hline Pavia & $\begin{array}{l}\text { Museo Castello } \\
\text { Visconteo }\end{array}$ & I & \\
\hline Rovigo & $\begin{array}{l}\text { Museo Accademia } \\
\text { Concordi }\end{array}$ & 2 & \\
\hline Venezia & Museo Archeologico & 2 & \\
\hline Trento & $\begin{array}{l}\text { Museo del Buon } \\
\text { Consiglio }\end{array}$ & 2 & \\
\hline Trieste & Museo Communali & I & \\
\hline Genova & Museo Archeologico & 3 & \\
\hline Bologna & Museo Civico & 7 & \\
\hline Parma & Museo Arcgeologico & 3 & II \\
\hline Firenze & Museo Archeologico & 16 & 11 \\
\hline Lucca & Museo Civico & 2 & \\
\hline Fiesole & $\begin{array}{l}\text { Museo Miss. } \\
\text { Francescana }\end{array}$ & I & 2 \\
\hline Cortona & $\begin{array}{l}\text { Museo Accademia } \\
\text { Estrusca }\end{array}$ & 2 & \\
\hline Vaticano & Museo Egizio & 5 & \\
\hline Napoli & Museo Nazionale & 6 & 2 \\
\hline TOTAL & & $|4|$ & 214 \\
\hline
\end{tabular}

Table 2 - Collections of Egyptian mummies in Italy.

\section{Evolution of the techniques used in mummies'studies}

It is clear that the mummies cited in this work are not simple articles displayed to the public like any other 
archaeological article. These human remains have aroused the attention of scientific researchers who made many publications about the subject.

The $20^{\text {th }}$ century is especially marked by the application of the new scientific techniques to the mummies' studies.

\subsection{Histology:}

In literature, many studies concerning Cairo mummies could be cited because they show the beginning of the application of histology to these human remains.

In the sales' catalogue of the Egypt Institute of Cairo, we can find the next titles:

- Furer (A.), I91 I. Histological studies on Egyptian
Egyptology site, we can find a publication referring to the use of radiography on mummies. We're talking about: - Derry, D. E., «An X-Ray Examination of the Mummy of King Amenophis I», $\mathrm{n}^{\circ}$ 34, pp. 47-48, ASAE, Cairo, 1934. Until these days, mummies are subject to radiography when they are studied. Mummies' radiographies show the skeleton's state allowing age and sex estimation as well as the discovery fractures or bones pathology.

\section{Medical Imaging:}

Medical imaging being perfectionned, the study of mummies could be made without deterioration of their bodies. Many ways of $\mathrm{X}$ rays application were used as well as the scanner or CT especially since nineties (Perpignan, Beyrouth, Barcelona, Chicago, Georgia...). Many authors based their studies on the use of these techniques like Bou and al. (1998) and Cesarini and al. like, for example, the reconstitution of face or body in three dimensions.

\section{Dental Examination:}

In the seventies, we can see the dental examination (Monier, 200I) applied to Egyptian mummies. Concerning this issue, we can cite the mummy of Perpignan whose denture was examined in 1985 and 1996 (Perraud, 200I). Much information could be retrieved of dental examination like teeth state and number, the presence or the absence of bacteria, the gingival state allowing a better knowledge of the subject's age, his diet and his oral disease.

\begin{tabular}{|l|l|c|c|}
\hline \multicolumn{1}{|c|}{ City } & \multicolumn{1}{c|}{ Museum } & Complete & Incomplete \\
\hline Aberdeen & Marischal Museum & $?$ & $?$ \\
\hline Dundee & Mc Manus Galleries & I E* & \\
\hline Edinburgh & Musée National de Scotland & II E & I E \\
\hline Leicester & $\begin{array}{l}\text { Leicestershire Museum and Art } \\
\text { Gallery }\end{array}$ & $5 \mathrm{E}$ & \\
\hline Liverpool & Liverpool Museum & $2 \mathrm{E}$ & I E \\
\hline London & British Museum & I0 E & \\
\hline Manchester & Manchester Museum & $24 \mathrm{E}$ & \\
\hline Oxford & Ashmolean Museum Oxford & $2 \mathrm{E}$ & \\
\hline Total & & $\mathbf{5 5}$ E & 2 E \\
\hline
\end{tabular}

Table 4 - Collections of Egyptian mummies in the United Kingdom.

mummies. Mémoire à l'Institut de l'Egypte, pp. 39;

- Rufer (M.A.), (1910). Remarks on the Histology and Pathological Anatomy of Egyptian mummies. Cairo Scientific Journal 40, I-5.

- Sandison (A.T.), 1955. The histological examination of mummified material. Stain Technology 30, pp. 277-283.

The histological studies of mummies continued during the all the 20th century.

Radiology:

On «Les Deux Terres» (the two lands), which is an

\section{Molecular Biology:}

The contribution of Molecular Biology is also important since it allowed the DNA analysis of many mummies like the ones of Italy (Rabino Massa, 1995), Lebanon (Hourani, 2000) or Spain (Barcelona).

Hair Analysis:

The study of mummies' hair can not be neglected. Hair composition can be modified by diet, cosmetic habits and certain diseases (Bertrand, 2003). During the last century, authors used the optical microscope, then the electronic microscope to examine the ultra structure of mummies hair (for example: Conti-Fuhrman and Rabino Massa (1972) and Rabino Massa and al. (1980)).

\section{Other Methods:}

Also the newest techniques of Physical-chemistry to study mummies are mass spectrometry for the chemical and biochemical appearance of the constituents (Denis, 1999) and the chromatography (Buckley and al. 1999). As well, endoscopies (Perraud, 200I) and anatomicalpathology (Denis, 1999) seem to be used in the study of mummies since the end of the last century. The anatomical-pathology allows, thanks to complete 
autopsies, to specify death reasons or the diseases of which suffered the mummy during her life.

\section{Conclusion}

In conclusion, though incomplete, our work located 64 collections of Egyptian and middle eastern mummies in 64 museums around the world with many unexpected results like the Palmyrian mummy of "Ny Carlsberg Museum", the one and only Palmyrian mummy outside Palmyra, the big number of Egyptian mummies at the "Rijksmuseum van Oudheden" in Holland or even the fragmented mummy of "Dubrovnik Archaeological Museum"...

Lots of researchers take mummies as a study object in a big number of Anthropological laboratories around the world trying to rebuild ancient environments, understand the genetic differences between human populations or analyse data and put into light the life styles of the past and also study the mummification procedures.

We are concerned, first of all, by the preservation of these mummies. For example, the Lebanese mummies, the only natural Middle Eastern mummies censed outside of Egypt (not taking into account the mummy Ginger of the British Museum and the Coptic mummy of the Allard Pierson Museum), are not preserved according to certain norms capable of conserving them for a long period but are simply lying down in boxes with formalin. This procedure is very primitive in comparison to empty coffins that allow avoiding decomposition due to Oxygen. In addition to their bad conservation, the studies headed around these mummies are very little developed. However, DNA sampling was made in 1996 but the results of this procedure did not appear yet.

On the other hand, the state of the Egyptian mummies is more satisfying. We are talking about their conservation and the studies headed around them. Almost all of the mummies we located in Europe were examined with new techniques like scanners and endoscopes and had DNA, tissues and hair sampling.

At last, the number of mummies in disposure of the researchers is becoming limited and Egyptians don't want their mummies to go out $f$ the country any more. Are there going to be new laws concerning mummies' studies? Are we going to find new mummies to study?

\section{Literature Cited}

Bertrand L. 2003. La mémoire des cheveux. Pour la Science, 306. (Online Magasine).

Bou C, Pomar P, Pessey J, Rabino-Massa E. 1998. Reconstitution faciale tridimensionnelle d'images tomodensitométriques par conception assistée par ordinateur: l'exemple d'une étude anthropologique. Revue de laryngologie, d'otologie et de rhinologie, Vol. I19, France.

Buckley SA, Stott AW, Evershed RP. 1999. Studies of organic residues from ancient Egyptian mummies using high temperature-gas chromatography-mass spectrometry and sequential thermal desorption-gas chromatography-mass spectrometry and pyrolysis-gas chromatography-mass spectrometry. Analyst, Vol. I24, United Kingdom.

Denis S. 1999. Le Dr. Patrice Josset. L'Anatomo-Pathologie appliquée à l'étude des momies. Les Archives des Laboratoires Publics, 37.

Fulcheri E, Baracchini P, Doro Garetto T, Pastorino A et Rabino Massa E. 1994. Le Mummie dell'antico Egitto custodite nei musei Italiani. Stima preliminare dell'ellentià del patrimonio museologico e considerazioni sul problrma della conservazione di esse. Lavoro parzialmente finanziato con fondi CNR, Torino, pp. I-4.

Hourani G. 2000. Chungara, Revista de Antropologia Chilena. Vol. 32, no. I, pp. 103-109. (Online Mgasine).

Monier T et A. 200I. La momie de Ramses II: étude paléopathologique d'un pharaon de la 19 ème dynastie. Société Francaise d'Histoire de l'Art Dentaire, France.

Rabino Massa E, Chiarelli B. 1972. The histology of naturally dessicated and mummified bodies. Journal of Human Evolution, I, pp. 259-262.

Rabino Massa E, Masali M, Contifurhman AM. 1980. Early Egyptian mummy hair: tensile strength tests, optical and scanning electron microscope observation. A paleopathological research. Journal of Human Evolution, $9 n^{\circ}$ 2: 133-137;

Rabino Massa E. 1995. DNA: un libro da leggere anche nelle mummie. Vedute sull'antico Egitto, Annuario IV Associazione Amici e Collaboratori del Museo Egizio di Torino: 132-143; http://2terres.hautesavoie.net/accueil2.htm 